\title{
A rare presentation of ocular lime injury
}

\author{
Deeksha Rani 두, Namrata Sharma, Rajesh Sinha, Rahul Kumar Bafna
}

Ophthalmology, Dr Rajendra Prasad Centre for Ophthalmic Sciences, All India Institute of Medical Sciences, New Delhi, India

\section{Correspondence to} Dr Rahul Kumar Bafna; rahulbafnae@gmail.com

Accepted 4 August 2020
Check for updates

(C) BMJ Publishing Group Limited 2020. No commercial re-use. See rights and permissions. Published by BMJ.

To cite: Rani D, Sharma N,
Sinha R, et al. BMJ Case
Rep 2020;13:e235889.
doi:10.1136/bcr-2020-
235889

\section{DESCRIPTION}

Alkalis (most common being lime) are responsible for $60 \%$ of the total ocular chemical burns. ${ }^{12}$ Hydroxyl ion released on alkali hydrolysis saponifies the fatty acids in the cell membranes causing cell lysis, facilitating deeper penetration of the alkali. Calcium ion reacts with the tissue, causing fibrosis and calcification. ${ }^{3}$ Here we report a rare presentation of ocular lime injury. A 5 -year-old boy presented to us with the history of lime falling into the left eye, 10 days ago. Immediate management including saline wash and lime particle removal was done at a local hospital and was referred to us for further management. On presentation, visual acuity in the right eye was 20/20 and in the left eye was hand movements at $30 \mathrm{~cm}(0.005$ decimals $) .{ }^{4}$ On slit-lamp examination, the left eye showed 360 degrees patchy limbal blanching with mucous discharge. The cornea was hazy with deep stromal infiltration measuring $(3 \times 5) \mathrm{mm}$ in the superior part of the cornea. The anterior chamber could not be visualised due to corneal oedema. Intraocular pressure was digitally normal. The fundal glow was poor and B-scan ultrasonography was normal. It was a severe ocular chemical burn that was graded as Grade IV burn as per Roper-Hall Classification $^{5}$ and Grade VI as per Dua's Classification. ${ }^{5}$ The child did not cooperate for anterior segment optical coherence tomography. Frequent antibiotics, cycloplegics, steroids, prophylactic antiglaucoma drugs, lubricants, sodium citrate and ascorbate were started. Microscope integrated optical coherence tomography (Mi-OCT) guided layer by layer dissection was planned. The intraoperative picture showed $360^{\circ}$ limbal ischaemia with associated haemorrhage from friable conjunctiva on the placement of speculum. Mi-OCT showed that infiltrate was in the deep corneal stroma and caused a shadowing effect (figure 1) with intact overlying epithelium. Partial-thickness dissection was started at the edge using a crescent knife. The anterior corneal lamella could be easily dissected off. Repeat Mi-OCT view of the chalky white substance revealed hyper-reflectivity. Status of descemet's and endothelium could not be assessed. Viscocohesive was injected through the side port and the whitish plaque was cut all-around using Vannas' scissors and sent for histopathological examination and culture. The defect was closed with an appropriately fashioned corneal patch graft (video 1). A plastic sheet (polythene cover of the intravenous set) was taken to mark the outlines of the defect. The mark was transferred to the donor cornea mounted on an artificial anterior chamber. The donor cornea patch was harvested and sutured to the host bed using 10-0 monofilament nylon. Amniotic membrane graft (AMG) was placed with

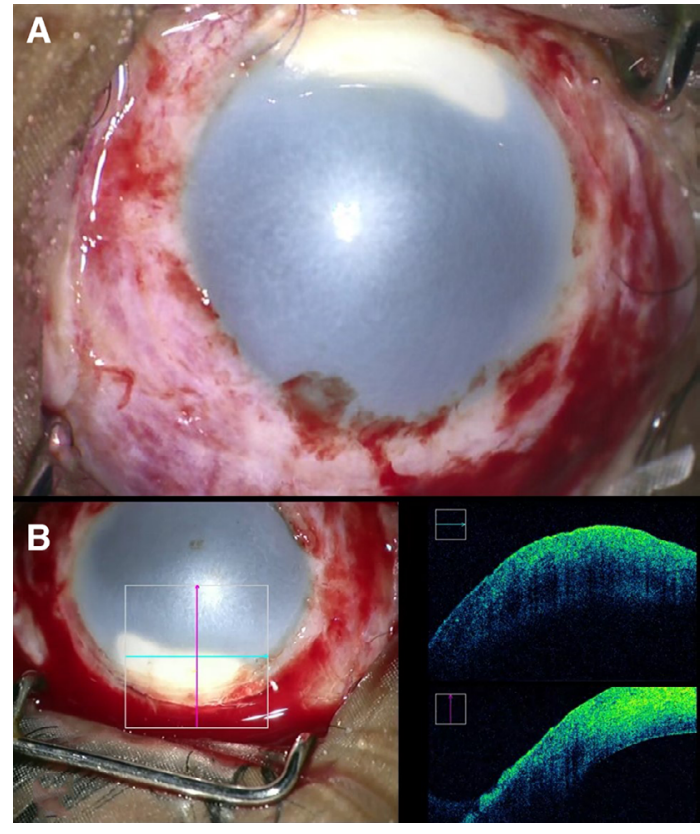

Figure 1 Intraoperative picture showing conjunctival blanching, superficial haemorrhages from friable conjunctiva, diffusely hazy cornea and $3 \times 5 \mathrm{~mm}$ sequestered deep stromal infiltration of unknown nature (A). Microscope integrated optical coherence tomography showed that infiltrate involved deep corneal stroma and caused a shadowing effect (B).

the epithelial side down and adhered using fibrin glue. AMG was supported at the limbus and lid margin using 8-0 polyglactin suture. Symblepharon ring was placed. Histopathological evaluation of the specimen revealed a dried-up tissue with fibrotic stroma with calcification. The $\mathrm{pH}$ of the tissue could not be assessed. Culture did not reveal any growth of a bacterial or fungal organism. Follow-up data could not be acquired as the child was lost to follow-up due to the current pandemic situation.

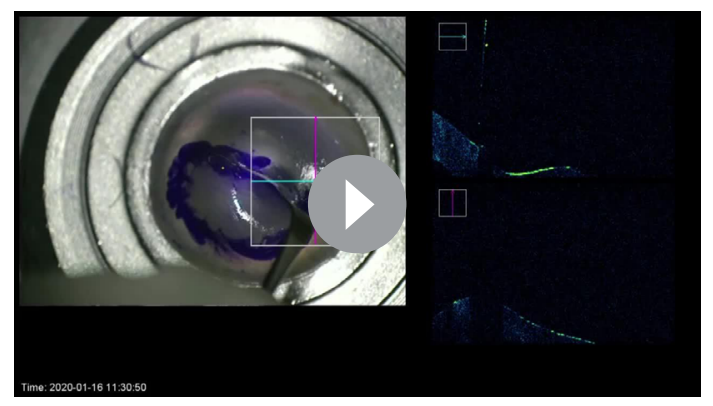

Video 1 Surgical video showing layer by layer lamellar dissection and corneal patch graft. 


\section{Learning points}

Sequestered whitish corneal infiltrate is a rare presentation of ocular alkali injury with the differential diagnosis of retained alkali material or tissue reaction to the chemical.

- Excisional biopsy is necessary to determine the nature of the sequestration.

- The primary intervention is needed to cause adequate healing so that a second stage visual rehabilitative procedure may be undertaken later.

Contributors NS: planning of the treatment. RKB: conducting the procedure, design. DR: acquisition of data. RS: interpretation and analysis of results.

Funding The authors have not declared a specific grant for this research from any funding agency in the public, commercial or not-for-profit sectors.
Competing interests None declared.

Patient consent for publication Parental/guardian consent obtained.

Provenance and peer review Not commissioned; externally peer reviewed.

\section{ORCID iDs}

Deeksha Rani http://orcid.org/0000-0002-3310-8021

Rahul Kumar Bafna http://orcid.org/0000-0002-6795-0508

\section{REFERENCES}

1 Maskati BT, Adrianwala SD. Chemical burns of the conjunctiva and cornea. J All India Ophthalmol Soc 1968;16:228.

2 Wagoner MD. Chemical injuries of the eye: current concepts in pathophysiology and therapy. Surv Ophthalmol 1997;41:275-313.

3 Sharma N, Kaur M, Agarwal T, et al. Treatment of acute ocular chemical burns. Surv Ophthalmol 2018;63:214-35.

4 Roper-Hall MJ. Thermal and chemical burns. Trans Ophthalmol Soc U K 1965:85:631-53.

5 Dua HS, King AJ, Joseph A. A new classification of ocular surface burns. Br J Ophthalmol 2001;85:1379-83.

Copyright 2020 BMJ Publishing Group. All rights reserved. For permission to reuse any of this content visit

https://www.bmj.com/company/products-services/rights-and-licensing/permissions/

BMJ Case Report Fellows may re-use this article for personal use and teaching without any further permission.

Become a Fellow of BMJ Case Reports today and you can:

- Submit as many cases as you like

- Enjoy fast sympathetic peer review and rapid publication of accepted articles

- Access all the published articles

- Re-use any of the published material for personal use and teaching without further permission

Customer Service

If you have any further queries about your subscription, please contact our customer services team on +44 (0) 2071111105 or via email at support@bmj.com.

Visit casereports.bmj.com for more articles like this and to become a Fellow 